\title{
KOMUNIKASI NONVERBAL
}

\author{
Muslim \\ Program Studi Komunikasi dan Penyiaran Islam STAI As-Sunnah Deli Serdang \\ Jl. Medan-Tg. Morawa, Km. 13 G. Darmo, Desa B. Sari, Kec. Tg. Morawa Kab. Deli Serdang \\ abufaqih@yahoo.com
}

\begin{abstract}
Abstrak: Komunikasi nonverbal adalah proses komunikasi dimana pesan disampaikan tidak menggunakan kata-kata dan bersifat simbol, yang artinya ambigu, abstrak, dan sewenang-wenang. komunikasi nonverbal ialah menggunakan gerak isyarat, bahasa tubuh, ekspresi wajah dan kontak mata, penggunaan objek seperti pakaian, potongan rambut, dan sebagainya, simbolsimbol, serta cara berbicara seperti intonasi, penekanan, kualitas suara, gaya emosi, dan gaya berbicara.
\end{abstract}

Kata kunci : Komunikasi, Nonverbal

\section{Pendahuluan}

Manusia sebagai makhluk sosial selalu berkomnikasi antara satu dengan lainnya, karena berkomunikasi merupakan bagian dari pada kebutuhan manusia. Pentingnya komunikasi bagi kehidupan sosial, budaya, pendidikan dan politik telah disadari oleh cendikiawan sejak Aristoteles. Akan tetapi, studi Aristoteles hanya berkisar pada rethorika. Baru pada pertengahan abad ke 20 ketika dunia dirasakan semakin kecil akibat revolusi industri dan revolusi tekhnologi elektronik, setelah ditemukan kapal api, pesawat terbang, listrik, telpon, surat kabar, film, radio, televisi dan sebagainya maka para cendikiawan pada abad sekarang menyadari pentingnya komunikasi ditingkatkan dari pengetahuan (knowledge) menjadi ilmu (science).

Para pakar telah merumuskan komunikasi dengan Caranya sendiri. “Thayer menemukan 25 artian komunikasi. Stappers menemukan 34 definisi. Battinghaus 50 rumusan dan Dance menemukan 98 buah". ${ }^{1}$ Sementara itu Anwar Arifin merujuk pendapat Fisher. Dimana ia mengatakan, "Ada lima katagori definisi komunikasi, Pertama, penyampaian atau pengoperan. Kedua, control sosial. Ketiga, sebagai fenomena stimuli respons. Keempat, kebersamaan arti dan kelima definisi yang melihat komunikasi sebagai integrator sosial".2

\footnotetext{
${ }^{1}$ Djajusman Tanudikusumah, Citra Komunikasi, Pidato Pengukuhan untuk jabatan guru besar tetap, (Jakarta: Universitas Indonesia, 1985), h. 65.

2 Anwar Arifin, Ilmu Komunikasi Sebuah Pengantar Ringkas, (Jakarta: PT.Raja Grafindo Persada, 2008) h.25.
} 
Istilah komunikasi yang dalam bahasa Inggris disebut communication berasal dari kata Latin communication dan bersumber dari kata communis yang berarti sama. Sama di sini maksudnya adalah sama makna. ${ }^{3}$ Jika terjadi komunikasi antara sesorang dengan orang lain atau dengan sekelompok orang, maka komunikasi akan terjadi selama ada kesamaan makna mengenai apa yang diperbincangkan. Kesamaan bahasa yang dipergunakan dalam percakapan itu belum tentu menimbulkan ke-samaan makna. Dengan kata lain, mengerti bahasanya saja belum tentu mengerti makna yang dibawakan oleh bahasa tersebut. Percakapan seseorang dengan orang lain dapat dikatakan komunikatif apabila kedua-duanya, selain mengerti bahasa yang digunakan, juga memengerti makna dari bahan yang dipercakapkan.

Juga Bahasa non verbal merupakan salah satu bentuk komunikasi yang sering digunakan dalam presentasi, dimana penyampaiannya bukan dengan katakata ataupun suara tetapi melalui gerakan-gerakan anggota tubuh yang sering dikenal dengan istilah bahasa isyarat atau body language. Selain itu juga, penggunaan bahasa non verbal dapat melalui kontak mata, penggunaan objek seperti pakaian, potongan rambut, dan penguins simbol-simbol.

Komunikasi nonverbal adalah proses komunikasi dimana pesan disampaikan tidak menggunakan kata-kata dan bersifat simbol, yang artinya ambigu, abstrak, dan sewenang-wenang ${ }^{4}$. Contoh komunikasi nonverbal ialah menggunakan gerak isyarat, bahasa tubuh, ekspresi wajah dan kontak mata, penggunaan objek seperti pakaian, potongan rambut, dan sebagainya, simbolsimbol, serta cara berbicara seperti intonasi, penekanan, kualitas suara, gaya emosi, dan gaya berbicara.

Para ahli di bidang komunikasi nonverbal biasanya menggunakan definisi "tidak menggunakan kata" dengan ketat, dan tidak menyamakan komunikasi nonverbal dengan komunikasi nonlisan. Contohnya, bahasa isyarat dan tulisan tidak dianggap sebagai komunikasi nonverbal karena menggunakan kata, sedangkan intonasi dan gaya berbicara tergolong sebagai komunikasi nonverbal. Komunikasi nonverbal juga berbeda dengan komunikasi bawah sadar, yang dapat berupa

\footnotetext{
3 Onong Uchjana Effendy, Komunikasi Teori dan Praktek, (Bandung: PT.Remaja Rosdakarya, 2006) h. 9

${ }^{4}$ Julia T.Wood, Komunikasi Teoridan Praktik, (Jakarta : Salemba Humanika, 2013), h.112.
} 
komunikasi verbal ataupun nonverbal. Dalam faktanya, penelitian telah menunjukkan bahwa $80 \%$ komunikasi antara manusia dilakukan secara nonverbal. Banyak interaksi dan komunikasi yang terjadi dalam masyarakat yang berwujud nonverbal. Komunikasi nonverbal ialah menyampaikanarti (pesan) yang meliputi ketidakhadiran simbol-simbol suara atau perwujudan suara. Salah satu komunikasi nonverbal ialah gerakan tubuh atau perilaku kinetic, kelompok ini meliputi isyarat dan gerakan serta mimic. Cara anda memuntir rambut atau menyentuh hidung, cara anda melipat tangan atau menyilangkan kaki, mengungkapkan banyak hal tentang Anda serta orang lain. Apakah ia menggoda Anda dari seberang ruangan? Jika demikian Anda dapat memberitahu padanya bahwa Anda tertarik dengan menggerai rambut Anda ke belakang atau menggoyangkan kaki. Jika ia mengibaskan jaketnya atau membenarkan mansetnya, ia tertarik pada diri Anda.

Di sebuah wawancara kerja, postur tubuh Anda mengatakan lebih banyak hal tentang Anda dibandingkan surat lamaran atau resume itu sendiri. Cara Anda duduk, tersenyum, dan menggunakan tangan mengatakan banyak hal tentang Anda. Apakah anda bersikap terbuka atau menyembunyikan sesuatu. Dengan mengetahui apa arti bahasa tubuh, anda dapat melihat perasaan seseorang yang sebenarnya, walau pun mereka tidak ingin mengatakannya kepada anda. 'Bahasa tubuh' kedengarannya seperti sebuah kontradiksi. Kita biasanya berbicara melalui mulut. Namun penelitian makin menemukan bahwa bahasa tubuh itu benar-benar sebuah bahasa. Mungkin dapat anda bayangkan kata-kata dan kalimat-kalimat yang terdiri dari gerak isyarat tubuh disengaja dan 'tanda-tanda' dari alam bawah sadar yang tidak disadari. Beberapa diantaranya merupakan gerakan-gerakan gugup yang cepat, merupakan tanda-tanda kecil yang hanya dapat ditangkap melalui pengawasan yang cermat. Sebuah gerakan tubuh seperti menjabat tangan seseorang adalah sebuah kata.

Sederetan gerakan tubuh yang berkesinambungan yang sering disebut kelompok, adalah kalimat.

Dalam kehidupan anak misalnya, anak-anak belajar beberapa hal tentang bahasa tubuh pada saat mereka tumbuh dan berkembang. Pada umur sepuluh, mereka tahu bahwa jika mereka berbohong dan tidak ingin mengaku, mereka 
harus mencoba untuk tidak menunduk dan melihat ke bawah atau tidak menutup bibir dengan tangan mereka. Kita semua memiliki beberapa pemahaman tentang bahasa tubuh, kecuali jika kita buta emosi. Anda tidak perlu mempunyai ijasah dalam ilmu psikologi untuk mengetahui bahwa seorang wanita yang memegangi kepalanya dengan tangannya sedang tidak bergembira. Makin akrab situasinya, makin banyak kita membuka diri yang sesungguhnya, makin banyak yang akan diungkapkan melalui bahasa tubuh kita, meskipun sering kali diluar kehendak kita. Kadang, tubuh kita menceritakan kebenaran yang tidak kita ketahui, dan tidak siap kita terima.

Tindakan nonverbal sangat erat kaitannya dengan konteks budaya. Salah mengartikan tindakan nonverbal dari orang-orang dengan budaya yang berbeda merupakan hal yang umum terjadi. Misalnya di Irak, jangan pernah berpikir bahwa mengacungkan jempol di Irak berarti wujud ekspresi dari sambutan hangat atau apresiasi positif terhadap seseorang karena di Irak tanda acungan jempol itu sama artinya dengan tanda mengacungkan jari tengah di Amerika dan masih banyak contoh lainnya. Hal ini menunjukkan bahwa meskipun banyak komunikasi nonverbal yang sifatnya universal, banyak tindakan nonverbal yang dibentuk oleh budaya.

Dalam terminologinya, komunikasi nonverbal merupakan proses komunikasi dimana pesan disampaikan tidak menggunakan kata-kata. Contoh komunikasi nonverbal ialah menggunakan gerak isyarat, bahasa tubuh, ekspresi wajah dan kontak mata, penggunaan objek seperti pakaian, potongan rambut, dan sebagainya, simbol-simbol, serta cara berbicara seperti intonasi, penekanan, kualitas suara, gaya emosi, dan gaya berbicara.

Sejak lahir hingga akhir hayat manusia, komunikasi non verbal merupakan sistem simbol yang sangat penting dalam kehidupan sehari-hari. Bayi mulai memahami kata-kata ketika umur 6 bulan, akan tetapi sebelum usia tersebut sebenarnya ia sudah mengerti komunikasi non verbal. Walaupun komunikasi nonverbal bersifat omnipresent (ada di mana-mana) namun ia merupakan resep penting dalam interaksi manusia. 


\section{Jenis-jenis Komunikasi Nonverbal}

1. Komunikasi objek

Komunikasi objek yang paling umum adalah penggunaan pakaian.Orang sering dinilai dari jenis pakaian yang digunakannya, walaupun ini dianggap termasuk salah satu bentuk stereotipe. Misalnya orang sering lebih menyukai orang lain yang cara berpakaiannya menarik. Selain itu, dalam wawancara pekerjaan seseorang yang berpakaian cenderung lebih mudah mendapat pekerjaan daripada yang tidak. Contoh lain dari penggunaan komunikasi objek adalah seragam

2.

Sentuhan

Haptik adalah bidang yang mempelajari sentuhan sebagai komunikasi nonverbal. Sentuhan dapat termasuk: bersalaman, menggenggam tangan, berciuman, sentuhan di punggung, mengelus-elus, pukulan, dan lain-lain. Masingmasing bentuk komunikasi ini menyampaikan pesan tentang tujuan atau perasaan dari sang penyentuh. Sentuhan juga dapat menyebabkan suatu perasaan pada sang penerima sentuhan, baik positif ataupun negatif.

\section{Kronemik}

Kronemik adalah bidang yang mempelajari penggunaan waktu dalam komunikasi nonverbal. Penggunaan waktu dalam komunikasi nonverbal meliputi durasi yang dianggap cocok bagi suatu aktivitas, banyaknya aktivitas yang dianggap patut dilakukan dalam jangka waktu tertentu, serta ketepatan waktu (punctuality.)

\section{Gerakan tubuh}

Dalam komunikasi nonverbal, kinesik atau gerakan tubuh meliputi kontak mata, ekspresi wajah, isyarat, dan sikap tubuh.Gerakan tubuh biasanya digunakan untuk menggantikan suatu kata atau frasa, misalnya mengangguk untuk mengatakan ya; untuk mengilustrasikan atau menjelaskan sesuatu; menunjukkan perasaan, misalnya memukul meja untuk menunjukkan kemarahan; untuk mengatur atau menngendalikan jalannya percakapan; atau untuk melepaskan ketegangan. 


\section{Proxemik}

Proxemik atau bahasa ruang, yaitu jarak yang Anda gunakan ketika berkomunikasi dengan orang lain, termasuk juga tempat atau lokasi posisi Anda berada. Pengaturan jarak menentukan seberapa jauh atau seberapa dekat tingkat keakraban Anda dengan orang lain, menunjukkan seberapa besar penghargaan, suka atau tidak suka dan perhatian Anda terhadap orang lain, selain itu juga menunjukkan simbol sosial. Dalam ruang personal, dapat dibedakan menjadi 4 ruang interpersonal :

a. Jarak intim

Jarak dari mulai bersentuhan sampai jarak satu setengah kaki. Biasanya jarak ini untuk bercinta, melindungi, dan menyenangkan.

b. Jarak personal

Jarak yang menunjukkan perasaan masing-masing pihak yang berkomunikasi dan juga menunjukkan keakraban dalam suatu hubungan, jarak ini berkisar antara satu setengah kaki sampai empat kaki.

c. Jarak sosial

Dalam jarak ini pembicara menyadari betul kehadiran orang lain, karena itu dalam jarak ini pembicara berusaha tidak mengganggu dan menekan orang lain, keberadaannya terlihat dari pengaturan jarak antara empat kaki hingga dua belas kaki.

d. Jarak publik

Jarak publik yakni berkisar antara dua belas kaki sampai tak terhingga.

5. Vokalik

Vokalik atau paralanguage adalah unsur nonverbal dalam suatu ucapan, yaitu cara berbicara. Ilmu yang mempelajari hal ini disebut paralinguistik.Contohnya adalah nada bicara, nada suara, keras atau lemahnya suara, kecepatan berbicara, kualitas suara, intonasi, dan lainlain. Selain itu, penggunaan suara-suara pengisi seperti "mm", "e", "o", "um", saat berbicara juga tergolong unsur vokalik, dan dalam komunikasi yang baik hal-hal seperti ini harus dihindari. 


\section{Lingkungan}

Lingkungan juga dapat digunakan untuk menyampaikan pesan-pesan tertentu. Diantaranya adalah penggunaan ruang, jarak, temperatur, penerangan, dan warna

\section{Mempelajari Komunikasi Nonverbal}

Karena pembelajaran komunikasi nonverbal sudah menjadi bagian dari "budaya popular" maka banyak orang memandang remeh dan menyalahartikan pelajaran yang kompleks ini, sehingga dalam topik ini akan dibahas beberapa masalah penting dan konsep yang potensial tentang komunikasi non verbal ini, yaitu:

1. Komunikasi Nonverbal dapat Bersifat Ambigu

Terkait dengan pesan yang disengaja dan tidak disengaja, kita perlu menyadari bahwa komunikasi nonverbal dapat memiliki derajat ambiguitas bermakna ganda- dimana tindakan nonverbal yang kita ekpresikan dapat ditafsirkan berbeda oleh orang lain. Sebagian ambiguitas ini terjadi karena komunikasi non verbal berdasarkan konteks.Misalnya ketika kita sedang berjalan dan tiba-tiba seseorang menyenggol kita dari arah belakang dan untuk motifnya kita sendiri tidak bisa langsung mengetahui apakah hal tersebut merupakan tindakan yang disengaja atau tidak.

\section{Faktor-faktor yang Memengaruhi Komunikasi Nonverbal}

Komunikasi nonverbal dapat dipengaruhi oleh banyak factor diantaranya: latar belakang budaya, latar belakang sosial ekonomi, pendidikan, gender, usia, dan juga kecenderungan pribadi. Artinya tidak semua orang dalam budaya tertentu melakukan tindakan non verbal yang sama.

3. Komunikasi nonverbal bersifat kontekstual

Situasi atau informasi yang berbeda akan menghasilkan pesan non verbal yang bebeda pula. Misalnya bagaimana kita bertingkah laku ketika sedang berada di rumah akan berbeda dengan tindakan yang kita lakukan ketika sedang berada di tempat umum, dan lain sebagainya.

\section{Komunikasi dan Budaya Nonverbal}

Rosenblatt menyatakan bahwa budaya mengajarkan kita tindakan non verbal apa yang ditunjukkan, arti dari tindakan tersebut dan latar belakang 
kontekstual dari tindakan tersebut. Sehingga dapat dikatakan bahwa komunikasi nonverbal memeainkan peranan penting dalam interaksi komunikasi antara orangorang dari budaya yang berbeda.

Dengan memahami perbedaan budaya dalam perilaku nonverbal, kita tida hanya akan dapat memahami beberapa pesan yang dihasilkan selama interaksi, namun kita juga akan dapat mengumpulkan petunjuk mengenai tindakan dan nilai yang mendasarinya.

\section{Klasifikasi Komunikasi Nonverbal}

Pesan yang dihasilkan oleh setiap kategori tidak berdiri sendiri, namun hadir bersamaan dengan pesan dari kategori yang lain yakni seprti pesan verbal, konteks, dan manusia sebagai penerima pesan.

Banyak klasifikasi membagi pesan non verbal ke dalam dua kategori komprehensif yaitu yang dihasilkan oleh tubuh (penampilan, gerakan, ekspresi wajah, kontak mata, sentuhan, dan parabahasa) dan hal-hal seperti ruang lingkup (tempat, waktu dan sikap diam).

\section{Perilaku Tubuh}

Komunikasi nonverbal yang dihasilkan oleh pengaruh tubuh ini antara lain mencakup: (a). pengaruh penampilan yakni kekuatan komunikasi untuk mendekatkan atau menjauhkan orang lain berasal dari bagaimana kita berpenampilan juga dari bahasa yang kita pergunakan, (b). menilai keindahan artinya apa yang dianggap indah pada suatu budaya belum tentu bagi budaya lainnya, (c). pesan dari warna kulit yamh bisa dijadikan penanda ras, (d). pesan dari pakaian, selain sebagai pelindung pakaian juga bentuk komunikasi. Pakaian dapat digunakan untuk menampilkan status ekonomi, pendidikan, status sosial, standar moral, dll, (e). gerakan tubuh (kinesik) yaitu bagaimana manusia berdiri, duduk dan berjalan memiliki pesan non verbal yang kuat atau juga dengan menyilangkan jari, mengacungkan jempol ke atas atau ke bawah, membuat lingkaran dengan tangan, menunjuk seeorang dll dapat memberikan arti tertentu sesuai konteksnya, (f). postur, postur sama pentingnya dengan wajah dalam menyatakan emosi seperti rasa takut. Di Jepang bungkukan yang sangat dalam menandakan rasa hormat. 


\section{Ekspresi wajah}

Bayi pun sebelum mengenal kata-kata pada usia 6 bulan sudah mampu membedakan ekspresi dengan melihat perubahan wajah orang tuanya.

3. Kontak mata dan tatapan

Mata sangat penting dalam komunikasi.Bahkan kalau di Amerika Serikat kurangnya kontak mata antara pasien dan penyedia jasa kesehatan akanmenimpulkan protes atau komplain. Budaya yang menggunakan kontak mata langsung antara lain seperti: Negara-negara Timur Tengah, Perancis, Jerman, dll. Sedangkan budaya yang menggunakan kontak mata sedikit antara lain seperti Korea, Jepang, Afrika, Pribumi Amerika, India Timur, dll.

4. Sentuhan

Sentuhan pun merupakan sarana komunikasi baik disentuh maupun menyentuh suatu objek tertentu.

5. Parabahasa

Nada suara manusia lebih dahsyat dari dawai atau seruling untuk menggerakkan jiwa terutama dalam 3 kategori berikut: (1). Kualitas vocal, (2). Karakteristik vocal dan (3). Pembeda vocal.

6. Ruang dan Jarak

Budaya memiliki pandangan dan penggunaan yang berbeda terhadap ruang gerak pribadi, tempat duduk dan pengaturan perabotan (mebel).

7. Waktu

Kita dapat memahami nilai budaya mengenai waktu dengan mempelajari bagaimana anggota suatu budaya memandang waktu seperti kecepatan dan ketepatannya terhadap waktu yang sangat jarang diajarkan secara eksplisit, melainkan berjalan di bawah alam sadar. Suatu konsepsi budaya mengenai waktu dapat diuji dari 3 (tiga) perspektif berbeda: (1). waktu informal, (2). persepsi mengenai masa lalu, masa kini, dan masa depan, (3). Klasifikasi monocronic dan polychronic milik Hall.

8. Sikap diam

Peribahasa Afrika menyatakan "Dalam diam kita dapat berkata-kata" artinya sikap diam dapat mengirimkan petunjuk nonverbal mengenai situasi komunikasi dimana anda berpartisipasi. Sikap diam juga membantu menyediakan 
umpan balik, menginformasikan baik penerima maupun pengirim mengenai kejelasan ide atau pentingnya hal tersebut dalam interaksi interpersonal secara keseluruhan. Penggunaan keheningan ini juga bervariasi dari satu budaya dengan budaya lainnya. Misalnya di Inggris, sikap diam akan diartikan sebagai ketidakyakinan, sedangkan di Igbo dianggap sebagai suatu penolakan. ${ }^{5}$

\section{Ayat-ayat Komunikasi Nonverbal :}

1. An-Naml, ayat : 19

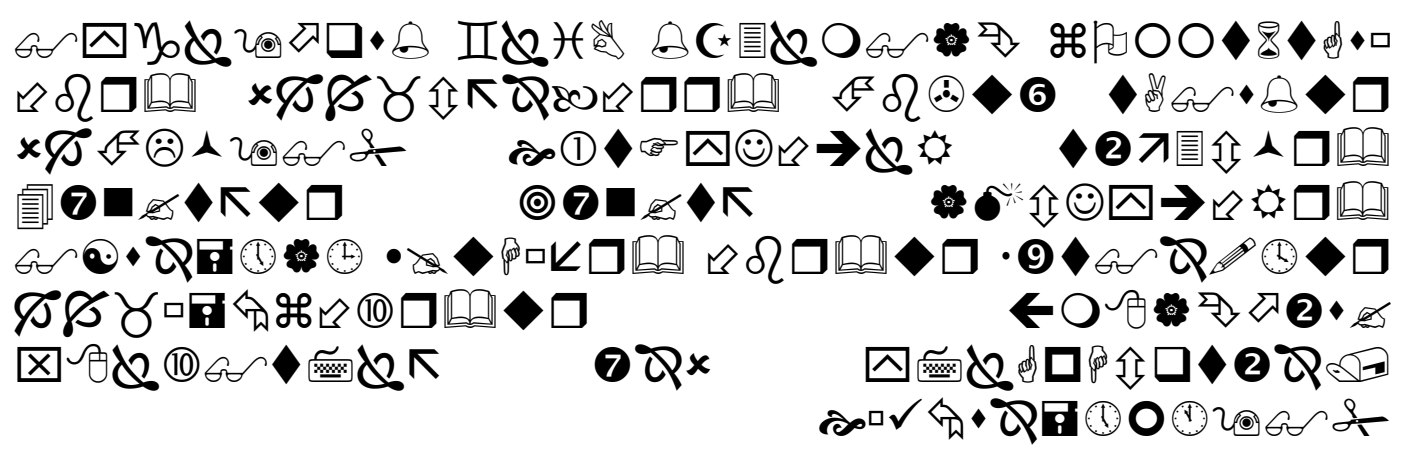

Maka dia tersenyum dengan tertawa Karena (mendengar) perkataan semut itu. dan dia berdoa: "Ya Tuhanku berilah Aku ilham untuk tetap mensyukuri nikmat mu yang Telah Engkau anugerahkan kepadaku dan kepada dua orang ibu bapakku dan untuk mengerjakan amal saleh yang Engkau ridhai; dan masukkanlah Aku dengan rahmat-Mu ke dalam golongan hamba-hamba-Mu yang saleh". ${ }^{6}$

Dalam ayat ini kita dapat satu cerita Yaitu bahwa ketika Nabi Sulaiman dan bala tentaranya dalam sebuah perjalanan dan sampai pada sebuah lembah بوَادِي السَّدِيرِ yang disebut sadir di thaif menuju lembah semut semut yang dikatakan kotadah di tanah syam yang berjarak antar dua lembah ini berkisar 3 mil. Saat itu, berkatalah seekor semut yang memiliki dua sayap yang bernama harmian وَقَالُوا اسْمَهَا حَرْمِيَا dengan penuh kekuatiran:

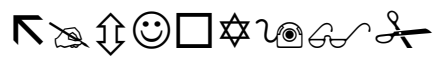

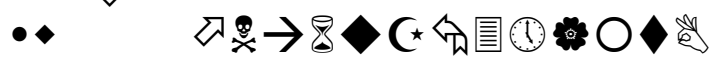

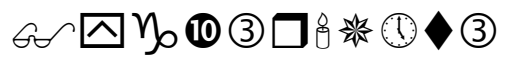

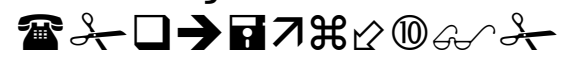

\footnotetext{
5 http://id.wikipedia.org/wiki/Komunikasi_nonverbal, html, diakses tanggal 22 September 2014.

${ }^{6}$ Quran Surah : An-Naml, Ayat : 19.

${ }^{7}$ Muhammad bin Ahmad Al-Qurtubi, Aljami’ liahkami Al-Qur'an (Kairo : Dar Al-Kutub AlMisriyah, 1964) juz. 10, hal.
} 


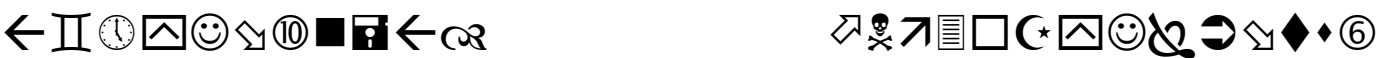

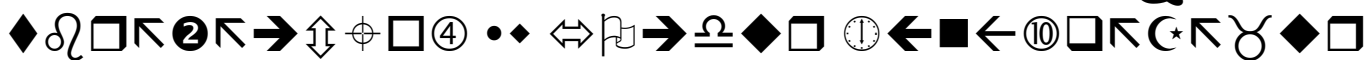

"Hai semut-semut, masuklah kamu sekalilan ke dalam lubang-lubang persembunyian kamu, agar kamu semua tidak diinjak oleh Nabi Sulaiman dan bala tentaranya." Sementara itu, Nabi Sulaiman dan bala tentaranya tidak merasa bahwa mereka telah menginjak para semut., ${ }^{8}$

Mendengar kekuatiran semut tersebut, Nabi Sulaiman tidak marah, akan tetapi dijelaskan dalam Al-Quran tersebut:

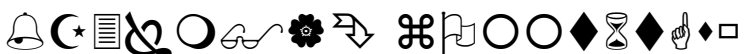

Yaitu respon yang diberikan adalah tersenyum dan tertawa, respon ini adalah merupakan komunikasi nonverbal yang dilakukan Nabi Sulaiman untuk menunjukkan ketakjubannya akan tindakan seekor semut yang mengultimatumkan kepada temannya untuk menghindar dari pasukannya.

Tersenyum dan disertai tawa adalah salah satu pengekspresian kata takjub. Athif Abul id mengatakan dalam bukunya yang berjudul the Art of Body Languange senyum yang ikhlas adalah senyum yang keluar dari hati yang berlangsung sekejap saja tidak melebihi empat detik, senyum tulus yang sejati dan suci merupakan tindakan baik yang mengekspresikan kebahagiaan yang megharubiru, rasa senang dan perasaan jujur. Hal tersebut merupakan sebuah keniscayaan dalam membangun relasi horizontal, membina persahabatan yang sukses, dan dalam membangun keterbukaan dalam keluarga. Bahkan dalam semua bentuk relasi humaniter; antara seorang saudara dengan saudara yang lainnya, antara teman dengan teman yang lainnya, antara seorang mitra dengan mitra lainnya atupu antar individu dengan yang lainnya. Ini mengingat senyuman tulus merepleksikan rasa cinta, kasih sayang terhadap yang menerima senyuman tersebut. ${ }^{9}$ Makanya nabi sulaiman dikatan bahwa beliau tersenyum dan disertai dengan tawa yang menunjukkan senyumnya hanya beberapasaat langsung dibubuhi dengan tawa untuk menunjukkan ketakjubannya.

Maka dalam tafsir taisir alkarimu ar-rohman dalam penafsiran ayat ini dijelaskan:

\footnotetext{
${ }^{8}$ Quran Surah : An-Naml, Ayat : 18

9 Athif Abul Id, The Art of Body Language, (Jakarta Timur : Pustaka Al-Kautsar Grup, 2009), hal. 101-102.
} 


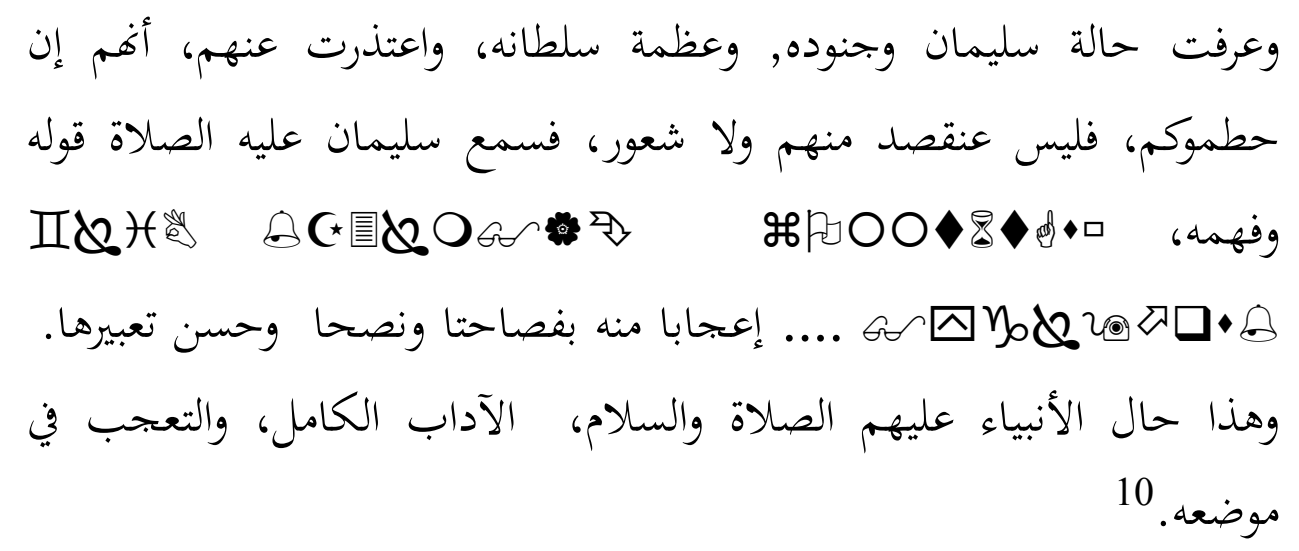

Artinya :

Ketika semut itu memahami keadaan sulaiman dan bala tentaranya, serta keagungan kekuasaannya dan uzur yang diberikannya dan seandainya juga menginjak para semut tanpa didasari unsur kesengajaan dan ketidak tahuan mereka kata semut tersebut kepada semut yang lain. Maka ketika sulaiman mendengar ucapan semut tersebut dan memahaminya maka ia tersenyum dan disertai tawa....yang menunjukkan ketakjubannya atas kepasihan, nasehat dan ungkapan yang baik dari semut tersebut. Dan inilah keadaan para nabi yang diutus oleh Allah dengan adab dan akhlak yang sempurna yang senantiasa meletakkan ketakjubannya pada tempatnya.

2. Surat Asy-Syuara', Ayat : 215

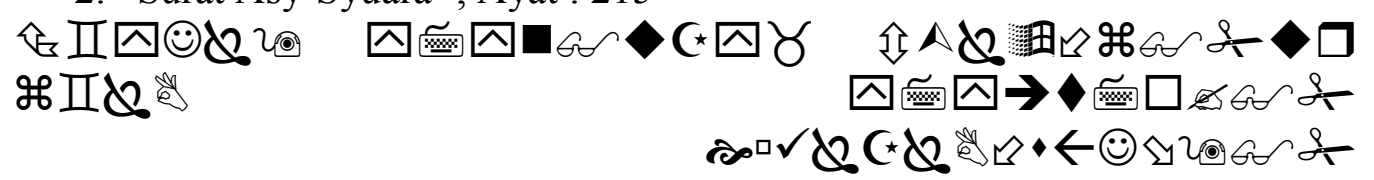

Dan rendahkanlah dirimu terhadap orang-orang yang mengikutimu, yaitu orang-orang yang beriman. ${ }^{11}$

Dalam ayat ini juga Lafadz حفض الجمناح dalam ayat ini adalah kinayah dari sikap tawadlu.

Ketika Rasulullah diperintahkan untuk mendakwahi keluarganya maka beliau dituntu untuk merendahkan dirinya yakni dengan tidak sombong kepada mereka, bersikap lembut kepada mereka, bertutur kata yang halus kepada mereka, mencintai mereka, berakhlak mulia dan berbuat ihsan kepada mereka ${ }^{12}$. Inilah

\footnotetext{
${ }^{10}$ Abdul Rahman bin Nasir As-Sa'di, Taisir Al-Karim Ar-Rahman, (Beirut-Libanon : Resalah Publisher, 2002), hal.603.

${ }^{11}$ Qur'an Surat Asy-Syuara', Ayat : 215

12 Abdul Rahman bin Nasir As-Sa'di, Taisir Al-Karim Ar-Rahman, hal. 599.
} 
akhlak Rasulullah shallallahu 'alaihi wa sallam; akhlak yang paling mulia yang dengannya tercapai berbagai maslahat.

3. Surat Al-Ahzab, Ayat : 21

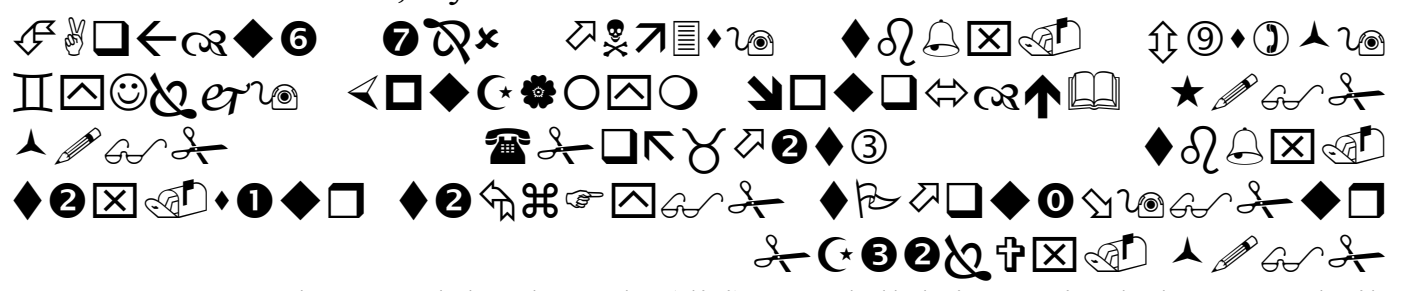

Sesungguhnya Telah ada pada (diri) Rasulullah itu suri teladan yang baik bagimu (yaitu) bagi orang yang mengharap (rahmat) Allah dan (kedatangan) hari kiamat dan dia banyak menyebut Allah. ${ }^{13}$

Ayat di atas menggambarkan bahwa Rasulullah berbudi pekerti yang mulia dan selalu memberikan tauladan sebagaimana pada perang khandak Beliau berani berperang dan terjun ke dalam kancah pertempuran yang kemudian Allah mengatakan bahwa Rasulullah adalah sebagai suri tauladan yang baik

Para ahli ushul berdalil dengan ayat ini tentang kehujjahan perbuatan Rasulullah shallallahu 'alaihi wa sallam. Demikian pula, bahwa hukum asalnya, umat Beliau mengikuti juga dalam hal hukum, kecuali ada dalil syar'i yang mengkhususkan untuk Beliau. ${ }^{14}$

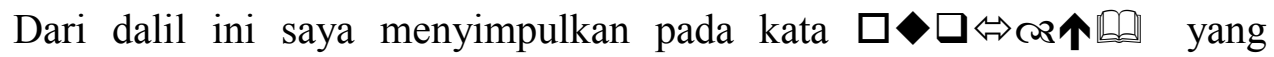
diartikan tauladan adalah salah satu bentuk komunikasinon verbal yang mengacu bahasa tubuh yang orang lain bisa menilai akan pelakunya.

Maka komunikasi nonverbal mencakup semua aspek komunikasi selain kata-kata itu sendiri. ${ }^{15}$ Jadi, ketika Rasul memberikan contoh adalah salah satu komunikasi yang dilakukan dari semuagerakan tubuh yang bernilai komunikasi nonverbal.

\section{Pustaka Acuan}

\footnotetext{
${ }^{13}$ Qur'an Surat : Al-Ahzab Ayat : 21.

${ }^{14}$ Abdul Rahman bin Nasir As-Sa'di, Taisir Al-Karim Ar-Rahman, hal. 661.

15 Julia T.Wood, Komunikasi Teoridan Praktik, hal. 112.
} 
Djajusman Tanudikusumah, Citra Komunikasi, Pidato Pengukuhan untuk jabatan guru besar tetap, Jakarta, Universitas Indonesia 1985.

Anwar Arifin, Ilmu Komunikasi Sebuah Pengantar Ringkas. Jakarta: PT.Raja Grafindo Persada, 2008.

Onong Uchjana Effendy. Komunikasi Teori dan Praktek. Bandung: PT.Remaja Rosdakarya, 2006.

Julia T.Wood, Komunikasi Teoridan Praktik. Jakarta : Salemba Humanika, 2013.

http://id.wikipedia.org/wiki/Komunikasi_nonverbal,

Muhammad bin Ahmad Al-Qurtubi. Aljami' liahkami Al-Qur'an. Kairo : Dar AlKutub Al-Misriyah, 1964.

Athif Abul Id. The Art of Body Language. Jakarta Timur: Pustaka Al-Kautsar Grup, 2009.

Abdul Rahman bin Nasir As-Sa'di Taisir Al-Karim Ar-Rahman. Beirut-Libanon : Resalah Publisher, 2002. 